\title{
ATTITUDES ON VACCINATION AMONG PORTUGUESE TRAVELERS AND BRAZILIAN MIGRANTS: A PILOT STUDY IN PORTUGAL
}

Ricardo Igreja ${ }^{1,3}$, Katy Barros ${ }^{2,3}$, Rosa Teodósio³

(C) 2019 by Acta Medica Saliniana ISSN 0350-364X

DOI: $10.5457 / 515$

Ricardo Igreja $a^{1,3}$ Katy Barros ${ }^{2,3}$

Rosa Teodósio ${ }^{3}$

\section{ABSTRACT}

Introduction: Anti-vaccination movements exist in Europe and it may reduce adherence to international vaccination.

Objectives: To evaluate attitudes on vaccination among Portuguese travelers and Brazilian migrants in Portugal.

Subjects and Methods: Between May and June 2019 a cross-sectional survey was carried out in the Travel Clinic of the Institute of Hygiene and Tropical Medicine of Lisbon. A self-administered questionnaire was applied after medical consultation. Travelers were asked about their attitudes to vaccines. An anonymous web-based survey was sent to Brazilian migrants living in Portugal for at least 6 months.

Results: 55 Portuguese (P) travelers and 22 Brazilian (B) migrants answered the questionnaire. $47.3 \%$ of Portuguese travelers were male; the mean age was 33 years; reason for travel: tourism (43.6\%) or business (30.9\%). 31.8\% of Brazilian migrants were male and the mean age was 44 years; $71.4 \%$ were living in Portugal for $\leq 2$ years. Attitudes towards vaccines: $64.8 \% \mathrm{P}$ and $68.2 \% \mathrm{~B}$ prefer to vaccine even when the risk of acquire a disease is low; $64.1 \% \mathrm{P}$ and $95.5 \% \mathrm{~B}$ consider that the resistance acquired by disease is better than resistance acquired by vaccine; $75.5 \% \mathrm{P}$ and $77.3 \% \mathrm{~B}$ prefer to vaccine even when diseases are not severe; $5.6 \% \mathrm{P}$ and $13.6 \% \mathrm{~B}$ don't take vaccines because they are afraid of side effects. About the reasons to accept a vaccine, travelers/ migrants consider very important to trust in the doctor (100\% P, 95.4\% B), and the excellent protective effect of a vaccine $(98.1 \% \mathrm{P}, 90.9 \% \mathrm{~B})$.

Conclusions: Portuguese travelers and Brazilian migrants in Portugal seem to have a favorable attitude towards vaccination, despite the anti-vaccination movements in Europe. They believe that trust in the doctor and excellent protection of the vaccines are reasons to accept it. The quality of traveler's advice may maintain/increase adherence to vaccination.

Key words: Travel Medicine, Vaccine, Attitudes

\section{INTRODUCTION}

Although, evidence clearly supports vaccination as the most cost effective approachto controlling infectious diseases there are many individuals questioning, delayingand refusing vaccines [1]. Anti-vaccination movements exist in Europe and it may reduce adherence to international vaccination.

The number of people traveling internationally has continued to grow substantially in the past decade [2]. Vaccines are one of the most cost effective and successful approaches to protecting individuals from a wide range of diseases, and have resulted in the prevention ofhundreds of thousands of deaths and millions of hospitalizations in the United States and worldwide [1]. Increasing rates of exemptions from vaccination are threatening to allow and already resulting in the re-emergence of many vaccine preventable diseases [1]. Recent outbreaks of vaccine-preventable diseases such as measles and mumps in the United States have been traced to contact with persons who had traveled to locations where vaccination was more prevalent. In addition, travel and migration have contributed to the recent introduction or reintroduction of vector-borne diseases in places that had previously been free from these diseases [2].

The status of travelers' knowledge, attitude, and practice (KAP) has been 
evaluated in previous studies [3-6]. The aim of the present study isto evaluate attitudes on vaccination among Portuguese travelers and Brazilian migrants in Portugal.

\section{SUBJECTS AND METHODS}

Between May and June 2019 a cross-sectional survey was carried out in two different groups. A self-administered questionnaire was applied to Portuguese travelers after medical consultation in the Travel Clinic of the Institute of Hygiene and Tropical Medicine of Lisbon. Travelers were asked about their attitudes to vaccines. A second group, composed by Brazilian migrants living in Portugal for at least six months, completed a similar anonymous web-based survey.

\section{RESULTS}

Fifty-five Portuguese travelers and twenty-two Brazilian migrants answered the questionnaire.

In the Portuguese group, $47 \cdot 3 \%$ of the travelers were male and the mean age was 33 years. The main reasons for travel were tourism (43.6\%) or business (30.9\%). The majority $(85.5 \%)$ had undergraduate or postgraduate degree. Africa was the most common destination (34.5\%), followed by Southeast Asia (30.9\%), Latin America (12.7\%) and multiple destinations (9.1\%). Among Brazilian migrants, seven (31.8\%) were male, the mean age was 44 years and $71.4 \%$ of them were living in Portugal for 2 years or less. The majority $(90.9 \%)$ had undergraduate or postgraduate degree.

\section{Traveler's attitudes towards vaccines:}

In the Portuguese group, $64.8 \%$ prefer to vaccine even when the risk of acquire a disease is low; $64.1 \%$ consider that the resistance acquired by disease is better than resistance acquired by vaccine; $75.5 \%$ prefer to vaccine even when diseases are not severe; and 5.6\% don't take vaccines because they are afraid of side effects.

About the reasons to accept a vaccine, $100 \%$ of travelers consider very important to trust in the doctor and 98.1\% of them the excellent protective effect of a vaccine.

\section{Migrant's attitudes towards vaccines:}

Among Brazilian migrants, $68.2 \%$ prefer to vaccine even when the risk of acquire a disease is low; $95.5 \%$ consider that the resistance acquired by disease is better than resistance acquired by vaccine; $77.3 \%$ prefer to vaccine even when diseases are not severe; and $13.6 \%$ don't take vaccines because they are afraid of side effects.

About the reasons to accept a vaccine, $95.4 \%$ of migrants consider very important to trust in the doctor and $90.9 \%$ of them the excellent protective effect of a vaccine.

\section{DISCUSSION}

Despite the demonstrated effectiveness of vaccines for reducing the mortality and morbidityof communicable diseases,vaccination rates are on the decline in many areas of the world.This has led to a commensurate resurgence of diseases thought to be largely controlled or eradicated. Recently, refusal to vaccinate has been related to outbreaks of whooping cough, measles, and other vaccine preventable illnesses [7].

Ohid Yaqub et al. [8] suggest that hesitant attitudes to vaccination are prevalent and may beincreasing since the influenza pandemic of 2009. They define hesitancy as an expression of concern ordoubt about the value or safety of vaccination. This means that hesitant attitudes are not confined only tothose who refuse vaccination or those who encourage others to refuse vaccination. For many people, vaccination attitudes are shaped not just by healthcare professionals but also by an array of other information sources, including online and social media sources. They found that healthcare professionals report increasing challenges tobuilding a trustful relationship with patients, through which they migh totherwise allay concerns and reassure hesitant patients [8].

Our study showed that as Portuguese travelers as Brazilian migrants in Portugal seem to have a favorable attitude towards vaccination, despite the anti-vaccination movements in Europe. They believe that trust in the doctor and excellent protection of the vaccines are reasons to accept it. It is in agreement with one study that showed that parents' confidence about adolescent vaccination was generally high. That study supported benefits of vaccination, harms of vaccination, and trust in healthcare providers [9].

MigrantswithintheEuropeanUnion(EU) mayrepresent an underimmunised group, with implications for outbreaks of vaccine-preventable diseases. Outbreaks of measles and hepatitis A have been documented in migrant populations in Europe. Migrants in the EU and European Economic Erea (EEA) are a diverse group, including both internal EU migrants - moving from one country in Europe to another - and external nonEU migrants [10]. As our group of Brazilian migrants in Portugal had a high level of education (90.9\% had undergraduate or postgraduate degree), it is possible that they were more up to dated to vaccines than the general population [3-5].

In a European survey a large majority of participants $(83.4 \%)$ considered vaccines in general to provide essential protection, and $34.7 \%$ considered them to be safe. However, $18.4 \%$ thought that they may cause side effects, $16.6 \%$ considered them to be expensive, $6.4 \%$ said that they were painful, $4.4 \%$ thought that they were not necessary, and $3.5 \%$ considered them to confer only minimal or no protection. Overall, 38.4\% had at least one negative attitude towards vaccines; this proportion was markedly lower in travelers leaving from Athens or 
Madrid, whereas the proportion of passengers at the London and Munich airports with negative attitude were much more critical [3]. Up to $76 \%$ of Australasian travelers believed that vaccination provides essential protection, $5 \%$ thought that vaccines were useless, $10 \%$ thought that vaccines had side effects, $4 \%$ found them painful, $7 \%$ considered them to be expensive, and $6 \%$ thought that they were unnecessary [4].

Vaccination was not considered essential for protection against infectious diseases by $9.4 \%$ of Spanish travelers, $16 \%$ questioned its efficacy, $46.5 \%$ considered vaccines to be expensive, $50.4 \%$ believed them to be painful, and $71.4 \%$ associated them with frequent side effects such as dizziness and fever. A total of $55.2 \%$ had not been vaccinated specifically for the journey, although $24 \%$ had received some vaccination for previous trips [5].

As our questionnaire was applied to Portuguese travelers just after a pre-travel medical consultation, it may have influenced the higher rate of acceptance of vaccines as compared to others studies that were performed at airports [3-5]. We think that the quality of traveler's advice may maintain/increase adherence to vaccination.

\section{SAŽETAK}

Uvod: Pokreti protiv vakcinacije postoje u Europi i mogu smanjiti prihvatanje međunarodnog cijepljenja. Ciljevi: Procijeniti stavove o cijepljenju među portugalskim putnicima i brazilskim migrantima u Portugalu.

Materijal i metode: Od maja do juna 2019. godine provedena je presječna anketa u Klinici za putničku medicinu Instituta za higijenu i tropsku medicinu u Lisabonu. Nakon savjetovanja s liječnikom primijenjen je upitnik. Putnicima je postavljeno pitanje o njihovim stavovima prema vakcinama. Anonimna anketa je putem interneta poslana brazilskim migrantima koji žive u Portugalu najmanje 6 mjeseci. Rezultati: 55 portugalskih (P) putnika i 22 brazilska (B) migranta odgovorilo je na upitnik. 47,3\% portugalskih putnika bili su muškarci; srednja životna dob bila je 33 godine; razlog putovanja: turizam $(43,6 \%)$ ili posao (30,9\%). 31,8\% brazilskih migranata bili su muškarci, a srednja životna dob 44 godine; $71,4 \%$ je živjelo u Portugalu $\leq 2$ godine. Stavovi prema vakcinama: $64,8 \%$ P i 68,2\% B preferiraju vakcinu čak i kada je rizik od dobivanja bolesti nizak; 64,1\% P i 95,5\% B smatraju da je otpornost stečena bolešću bolja od otpornosti stečene vakcinom; 75,5\% $\mathrm{P} \mathrm{i}$ 77,3\% B preferiraju vakcinu i kad se radi o bolestima koje nisu teške; 5,6\% P i 13,6\% $B$ se ne vakcinišu jer se plaše nuspojava. $O$ razlozima za prihvaćanje vakcine, putnici/migranti smatraju vrlo važnim povjerenje u liječnika (100\% P, 95,4\% B) i odličan zaštitni učinak vakcine $(98,1 \%$ P, 9o,9\% B).

Zaključci: Izgleda da portugalski putnici i brazilski migranti u Portugalu imaju povoljan stav prema vakcinaciji, unatoč pokretima protiv vakcinacije u Europi. Oni vjeruju da su povjerenje u liječnika i odlična zaštita vakcina razlog da se to prihvati.
Kvalitetno savjetovanjea putnika može održati/ povećati prihvatanje vakcinacije.

Ključne riječi: putnička medicina, cjepivo, stavovi

\section{REFERENCES}

1. Griffin DS, Muhlbauer G, Griffin DO. Adolescents trust physicians for vaccine information more than their parents or religious leaders. Heliyon2o18; eo1oo6. doi:10.1016/j.heliyon.2018. eo10o6

2. El-Ghitany EM, Mohamed Abdelmohsen MA, Farghaly AG et al.Knowledge, attitude, and practice among Egyptian travelers: pretravel vaccination and malaria prophylaxis. Int J Travel Med Glob Health 2018;6(3):125-136. doi:10.15171/ijtmgh.2018.23.

3. Van Herck K, Van Damme P, Castelli F, et al. Knowledge, attitudes and practices in travelrelated infectious diseases: the European airport survey. J Travel Med. 2004;11(1):3-8. doi:10.2310/7060.2004.13609.

4. Wilder-Smith A, Khairullah NS, Song JH, Chen CY, Torresi J. Travel health knowledge, attitudes and practices among Australasian travelers. J Travel Med. 2004;11(1):9-15. doi:10.2310/7060.2004.1360o.

5. Lopez-Velez R, Bayas JM. Spanish travelers to high-risk areas in the tropics: airport survey of travel health knowledge, attitudes, and practices in vaccination and malaria prevention. J Travel Med. 2007;14(5):297-305. doi:10.1111/j.1708-8305.2007.00142.x.

6. Teodosio R, Goncalves L, Atouguia J, Imperatori E. Quality assessment in a travel clinic: a study of travelers' knowledge about malaria. J Travel Med. 2006;13(5):288-293. doi:10.1111/j.1708- 8305.2006.0006o.x.

7. Martin LR, Petrie KJ. Understanding the Dimensions of Anti-Vaccination Attitudes:the Vaccination Attitudes Examination (VAX) Scale. Ann. Behav. Med.DOI 10.1007/s12160o17-9888-y

8. Yaqub O, Castle-Clarke S, SevdalisN, Chataway J. Attitudes to vaccination: A critical review. Social Science \& Medicine. 2014; 112:1-11.

9. Gilkey MB, Magnus BE, Reiter PLet al.The Vaccination Confidence Scale: A Brief Measure of Parents' Vaccination Beliefs. Vaccine. 2014; 32(47):6259-6265. doi:10.1016/j. vaccine.2014.09.007.

10. Ravensbergena SJ, Nellums LB, Hargreaves S et al. National approaches to the vaccination of recently arrived migrants in Europe: A comparative policy analysis across 32 European countries. Travel Medicine and Infectious Disease. 2019; 27:33-38. 